\title{
국내외 $\mathrm{SBM}$ 설치 사례 분석을 통한 적지평가 기준에 관한 연구 \\ † 윤귀호 - 박준모* \\ † 한국해양대학교 교수, * 한국해양대학교 대학원
}

\section{A Study on the Standard for Proper Position Rating Through Analysis of SBM Installation cases at home and abroad}

\author{
+ Gwi-Ho Yun ·Jun-mo Park \\ + Professor of Korea Maritime University, Busan 606-791, Korea \\ * Graduate school of Korea Maritime University, Busan 606-791, Korea
}

\begin{abstract}
요 약 : 우리나라는 전 세계적으로 많은 원유를 수입하는 국가 중 하나이다. 그리고 국내 몇몇 항들은 수입한 원유를 육상시설로 이송하기 위한 원유브이를 운영하고 있다. 이러한 상황에서 최근 울산항은 울산 신항의 개발에 따른 방파제 신설로 기존에 설치되어 있는 원유브이를 이 설하고, 추가적으로 1 기의 원유브이를 신설할 예정이다. 이에 따라 이설 및 신설하고자 하는 원유브이의 최적 위치 설정이 필요하게 되었는데 현재 국내외적으로 원유브이 위치 설정에 대하여 체계적이고 일관된 기준이 수립되어 있지 않은 실정이다. 이에 본 연구에서는 국내외 원유브 이 설치 운영 사례에 관한 선행 연구 자료를 분석 검토하고, 관련 기관 및 전문가 의견 수렴 결과를 바탕으로 한 분배율을 제시하고, 단순가중 치 첨가법(SAW)을 이용하여 원유브이 설치 기준을 제시하고자 한다.
\end{abstract}

핵심용어 : 원유브이, 최적 위치, 의견 수렴, 분배율, 단순가중치 첨가법(SAW), 설치 기준

\begin{abstract}
Korea is one of the world's major oil importers. And a few domestic ports are operating SBMs for transferring imported crude oil to shore facilities. Recently, Ulsan port is planning to install additional new SBM and to move the existing two SBMS to other places according to the establishment of breakwater caused by the development of UIsan New Port. However, there are no systematic and consistent standards for fixing the most suitable position domestically and internationally. This study aims to propose the standard of SBM installation using SAW after analyzing the examples of SBM operation and previous researches at home and abroad, and proposing the distribution rate based on opinion survey of exports and related organizations
\end{abstract}

Key words : SBM, The most suitable position, Opinion survey, SAW, Standard of installation.

\section{1. 서 론}

우리나라는 세계적으로 많은 원유를 수입하는 국가 중에 하나로서, 국내 몇몇 항구에 수입된 원유를 이송하고 저장할 수 있는 대규모 설비를 갖추고 있다. 원유의 수출입은 일반 적으로 초대형 원유운반선에 의해 이루어지는데, 이러한 선 박의 원유 적·양하를 위해 많은 국가에서는 부두시설 건설에 따른 비용 및 항만시설 포화상태 등의 이유로 부두시설을 대신하여 원유브이를 설치·운영하고 있다.

그러나 상대적으로 높은 위험성을 내포하고 있는 원유브 이 설치에 대한 적절한 기준이 국내외적으로 확립되어 있지 않은 실정이다. 따라서 원유브이와 관련된 해양사고가 발생 할 경우 큰 피해가 우려되고, 최근 울산항에서 원유브이의
이설 및 신설이 예정되면서 이에 대한 체계적인 설치기준 수 립의 필요성이 더욱 대두되고 있는 상황이다.

이에, 본 연구에서는 이러한 상황과 필요성의 인식에 근거 하여 국내외 원유브이 설치 운영 사례 및 선행 연구 자료를 분석 검토하고, 관련 기관 및 전문가 의견 수렴을 바탕으로 원유브이 설치 위치에 영향을 미치는 목적함수를 도출하고, 각 요소들에 대한 가중치를 제시한다. 그리고 목적함수에서 항목별로 분배율을 $0 \sim 4$ 로 설정하여 단순가중치 첨가법을 이용한 원유브이 최적 설치 위치를 점수화하였으며, 이를 이 용하여 원유브이 설치에 대한 정량적인 판단을 할 수 있는 기준을 제시한다. 이와 같은 원유브이 국내 설치기준 제시는 현재 진행되고 있는 원유브이 설치 공사 시 시공사와 사용자 의 마찰을 줄일 수 있을 뿐만 아니라, 원유브이 및 원유브이

† 종신회원, captyun@hhu.ac.kr 051)410-4471

* 정회원, jmpark@hhu.ac.kr 051)410-4476

(주) 이 논문은 “국내외 SPM 설치 사례 분석을 통한 국내 설치 기준 연구”란 제목으로 "2012학술대회 한국항해항만학회논문집(경주 교육문화회관, 2012.6.4.21-23, pp.355-357)”에 발표되었음. 
를 이용하는 선박의 안전 확보 측면에서도 도움이 될 것으로 사료된다.

\section{2. 국내외 원유브이 설치 및 운영 사례}

국내외에 설치되어 운영 중인 원유브이를 조사하기 위해 서 영국의 Shipping Guide Ltd.에서 발간하는 Guide to Port $\operatorname{Entry}(2011$ 2012)자료(Shipping Guide Ltd., 2010)를 활용하 였다. 단, 조사대상 원유브이는 설치조건이 다소 열악한 경우 로 주변의 항만 및 수역시설에 인접하여 설치된 것으로 제한 한다. 또한 원유브이를 이용할 수 있는 최대 규모 선박의 길 이는 일반화물선의 톤수 그룹별 대표선박 길이를 사용하였 다.

\section{1 국내 원유브이 설치 사례}

국내에 원유브이를 설치하여 운영 중인 항만은 대산, 울산 및 거제 지세포로, 해당 항만에 설치되어 있는 원유브이와 장 애물과의 이격거리는 Table 1 과 같다. Table 1 의 내용 중 L은 $300,000 \mathrm{DWT}$ 급 선박의 L.O.A(Length over all)인 330m로 설 정하였다. 즉, 국내 원유브이는 해상에 고정되어 있는 구조물 인 브이, 부두, 방파제 및 육지와의 이격거리가 대부분 $3.0 \mathrm{~L}$ 을 초과하였으며, 항로와의 거리는 고정된 구조물보다 상대적으 로 작은 이격거리를 유지하고 설치되어 있다.

Table 1 SBM installation status in domestic ports

\begin{tabular}{|c|c|r|c|c|}
\hline \multirow{3}{*}{ Port } & \multirow{2}{*}{ Obstruction } & \multirow{2}{*}{ Distance } & \multicolumn{2}{|c|}{ Ship's Capacity } \\
\cline { 3 - 3 } & & & DWT & Ratio \\
\hline \multirow{3}{*}{ Daesan } & Fairway & $107 \mathrm{~m}$ & & $0.3 \mathrm{~L}$ \\
\cline { 2 - 3 } & Buoy & $1,050 \mathrm{~m}$ & \multirow{2}{*}{300,000} & $3.2 \mathrm{~L}$ \\
\cline { 2 - 3 } & Berth & $1,440 \mathrm{~m}$ & & $4.4 \mathrm{~L}$ \\
\hline \multirow{3}{*}{$\begin{array}{c}\text { Ulsan } \\
\text { SK \#2) }\end{array}$} & Fairway & $580 \mathrm{~m}$ & & $1.8 \mathrm{~L}$ \\
\cline { 2 - 3 } & SBM & $1,020 \mathrm{~m}$ & \multirow{2}{*}{300,000} & $3.1 \mathrm{~L}$ \\
\hline \multirow{2}{*}{ Jisepo } & Breakwater & $1,020 \mathrm{~m}$ & & $3.1 \mathrm{~L}$ \\
\hline & Island & $906 \mathrm{~m}$ & \multirow{2}{*}{300,000} & $2.7 \mathrm{~L}$ \\
\cline { 2 - 3 } & Shallow water & $1,192 \mathrm{~m}$ & & $3.6 \mathrm{~L}$ \\
\hline
\end{tabular}

\section{2 국외 원유브이 설치 사례}

국외 항만의 경우도 여러 나라에서 원유브이를 설치 운영하 고 있으나 해상의 구조물과 같은 장애물과 인접한 곳에 원유브 이가 설치된 주요 사례만을 조사하였으며, 그 결과는 Table 2 와 같다. Table 2의 내용 중 40,000DWT급 선박의 L(Length over all)은 235m, 60,000DWT급 선박은 $250 \mathrm{~m}, 320,000 \mathrm{DWT}$ 및 $360,000 \mathrm{DWT}$ 급 선박은 $330 \mathrm{~m}$ 로 설정하였다. 즉, 국외의 원
유브이도 대부분 장애물과 약 $3.0 \mathrm{~L}$ 이상의 이격거리를 두고 설 치하는 것을 알 수 있다.

Table 2 SBM installation status in foreign ports

\begin{tabular}{|c|c|c|c|c|}
\hline Port(Country) & Obstruction & Distance & \multicolumn{2}{|c|}{ Ship's Capacity } \\
\cline { 4 - 5 } & DWT & Ratio \\
\hline $\begin{array}{c}\text { BANDAR TAHERI } \\
\text { (IRAN) }\end{array}$ & Berth & $796 \mathrm{~m}$ & 40,000 & $3.4 \mathrm{~L}$ \\
\hline $\begin{array}{c}\text { SALINA CRUZ } \\
\text { (MEXICO) }\end{array}$ & Berth & $792 \mathrm{~m}$ & 60,000 & $3.2 \mathrm{~L}$ \\
\hline $\begin{array}{c}\text { ALGECIRAS } \\
\text { (SPAIN) }\end{array}$ & Berth & $904 \mathrm{~m}$ & 320,000 & $2.7 \mathrm{~L}$ \\
\hline $\begin{array}{c}\text { DAS ISLAND } \\
\text { (U.A.E) }\end{array}$ & Berth & $1,470 \mathrm{~m}$ & 360,000 & $4.5 \mathrm{~L}$ \\
\hline
\end{tabular}

\section{3. 선행연구 및 관련 규정}

종전까지 원유브이 설치 위치 결정에 있어 기존의 연구결과, 원유브이 운영기업의 자체 기준 및 선급 기준 등을 바탕으로 결정하다 보니 그 결과가 객관적이지 못하고 일관성이 없을 뿐 만 아니라 확대되는 항만시설, 좁은 항계 등 현재의 항만환경 을 반영하지 못했기 때문에 시공사와 사용자간에 마찰의 원인 이 되었다. 이에 객관적인 원유브이 적지평가 기준 제시를 위 하여 기존 원유브이 설치 위치 결정의 참고자료로 활용하는 선 행 연구 결과, 원유브이 운영기업의 자체 기준 및 선급 기준 등을 조사 분석하여 현재의 항만 환경이 반영된 원유브이 적지 평가 기준을 제시하고자 한다.

\section{1 선행 연구 조사}

1) 한국해양수산연구소 보고서

울산의 중앙방파제 건설에 따른 원유브이 운용 안전성에 관 한 보고서(Korea Institude of Maritime and Fisheries Technololy, 1999)에서 원유브이의 제한수역을 통항선박이 침 범하지 않도록 충분한 이격거리를 유지해야 하며, 원유브이를 중심으로 반경 $1,220 \mathrm{~m}$ 이내에는 장애물이 없어야 한다고 언급 하고 있다.

2) 선박안전기술공단 연구 보고서

선박안전기술공단에서는 원유브이 이안 선박의 조종영역에 관한 연구(Korea Ship Safety Technology Authority, 2007)를 실시하였으며, 그 결과 원유브이를 이용하는 선박의 조종영역 은 물리적인 조종영역인 $1.9 \mathrm{~L}$, 선박 조종자의 심리적 여유거리 인 $1.0 \mathrm{~L}$ 을 합한 $2.9 \mathrm{~L}$ 이 필요한 것으로 나타났다고 언급하고 있 다. 
3) 좁은 수로에서 대형 원유선의 모형시험 결과 보고서

유의파고에서 대형 원유선 흘수의 1.1 배, 1.15 배, 1.2 배 수심 에서 약 $7 \mathrm{kts} \sim 8 \mathrm{kts}$ 의 속력으로 항해시 선체 침하현상으로 인해 선저가 해저에 접촉되므로 원유선이 접·이안하는 부근수 역은 접·이안 예상선박의 최대흘수의 최소 1.2 배 이상의 수심 이 확보되어야 한다고 언급하고 있다.

\section{2 관련 규정 조사}

1) 국제석유회사평의회(OCIMF) 권고

국제석유회사평의회에서 원유브이와 관련하여 권고하고 있 는 규정으로는 원유브이의 안전운영을 위해 원유브이를 중심 으로 반경 $2,400 \mathrm{~m}$ 이내에는 장애물이 없어야 한다(OCIMF, 1993)고 언급하고 있다.

2) 미국선급 $(\mathrm{ABS})$ 및 한국선급 $(\mathrm{KR})$ 규정

원유운반선이 원유브이에 접안하기 위한 조선반경은 최대 접안선박 길이의 최소 3 배는 되어야 한다고 규정하고 있다 (ABS, 1975; KR, 2001).

3) 항만 및 어항설계 지침

국내 항만 및 어항시설물의 계획 및 기준을 정하고 있는 동 기준의 제 14 편 초대형석유탱커 시설, 제 2 장 위치선정과 시설계 획에 단지 초대형석유탱커가 안전하고 원활하게 접이안하고 계류 및 하역이 될 수 있는 위치로 선정해야 한다(Ministry of Oceans and Fisheries, 2005)고 언급하고 있다.

\section{4) $\mathrm{SK}$ (주) 자체 기준}

$\mathrm{SK}$ (주)는 원유브이 설치 운영에 오랜 경험을 가지고 있는 정유업체로 원유브이 설치 및 운영과 관련된 자체기준을 마련 하고 있다. 이 규정 중 해저배관에 대해서는 가급적 항로를 피 하여 선박의 주묘, 항해중 선박의 긴급 비상투묘 등으로 인한 해저배관 손상을 예방하기 위해 해저배관을 매설해야 한다고 언급하고 있다. 또한 장애물과는 최소한 선박길이의 4 배를 확 보해야 하나, 수심 대 흘수의 깊이인 선저 안전수심과도 관계 되는 것으로 조건이 매우 나쁜 해역에서는 원유선 길이의 4 배, 조건이 그렇게 나쁘지 않을 경우는 선박 길이의 3 배 정도가 필 요하다고 언급하고 있다. 그리고 원유브이의 점검 및 보수 측 면과 수심이 너무 깊은 외해에 설치할 경우 높은 파고의 영향 으로 접안가능일수가 감소할 수 있다는 측면 등을 종합적으로 고려할 때에 원유 브이의 수심은 $30 \mathrm{~m}$ 이내이어야 한다고 규정 하고 있다.

\section{4. 원유브이 설치 시 영향 요인 분석 및 전문가 의견 수렴}

해상에 설치되는 원유브이는 대형 원유운반선이 계류한다는 측면만 고려해도 안전성이 일반적인 부두에 비해 상당히 떨어 질 수밖에 없으며, 접안된 선박은 원유브이를 중심으로 일정한 반경을 갖고 움직인다는 점과 원유브이의 설치위치가 부두보 다 상당히 외해에 설치되어 있어 외력의 영향을 많이 받을 수 있다는 점 등을 감안할 때에 원유브이를 설치할 때에는 많은 요소들을 종합적으로 고려해야 한다.

\section{1 원유브이 설치 시 영향 요인 분석}

선행연구 및 관련 규정 등을 근거로 원유브이를 설치하여 운영하는데 고려해야 할 요소들을 장애물 요인(브이와의 거리, 방파제와의 거리, 부두와의 거리, 항로 및 정박지와의 거리, 선 저수심), 환경 요인(해저저질 종류, 기상상태) 및 편리성으로 나누어 분류하였다. 이 영향 요인을 기초로 전문가 집단을 대 상으로 의견수렴을 실시하여 중요도를 수치화하고, 각 요인에 대한 가중치를 제안하고자 한다.

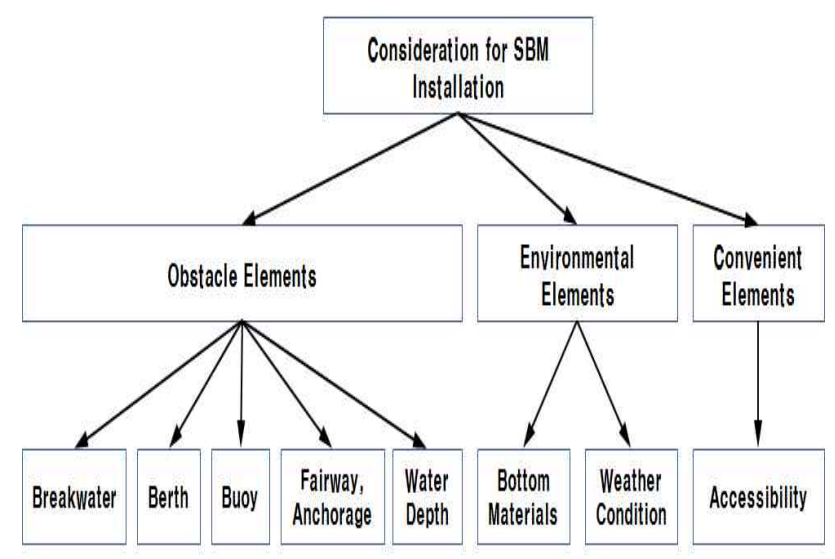

Fig 1. Considerations for SBM installation

\section{2 원유브이 설치요건에 대한 의견 수렴}

원유브이 설치 요건에 대한 기준을 마련하기 위하여 4.1절 에서 도출된 영향 요인 분석 결과를 토대로 Table 3과 같이 관 련 기관 및 전문가들로부터의 의견수렴 과정을 진행하였다. 의 견수렴 절차는 우선 원유브이를 운영하고 설치하는데 있어 이 해관계 있는 기관과 관련 분야에 전문 지식을 가지고 있는 전 문가를 선별한 후 실시하였으며, 의견수렴의 내용은 원유브이 설치 시 고려해야 할 요소 중 가장 우선적으로 반영되어야 할 조건에 대한 질의였다. 
Table 3 Consultation outline

\begin{tabular}{|c|l|}
\hline $\begin{array}{c}\text { Consultation } \\
\text { Item }\end{array}$ & \multicolumn{1}{|c|}{ Contents } \\
\hline & $\begin{array}{l}\text { - Korea maritime university } \\
\text { - Mokpo national maritime university } \\
\text { - Ulsan regional maritime affair and port } \\
\text { office } \\
\text { - Ulsan port authority } \\
\text { Group }\end{array}$ \\
& $\begin{array}{l}\text { - Ulsan pilot } \\
\text { - Oil company }\end{array}$ \\
\hline Period & \multicolumn{1}{|c|}{ 2012. 03 2012. 04 } \\
\hline Number & \multicolumn{1}{|c|}{ E-mail. Telephone, Interview } \\
\hline Method & \multicolumn{1}{|c|}{} \\
\hline
\end{tabular}

Table 3과 같이 의견수렴을 진행한 결과 Table 4와 같이 선 박통항로, 방파제와 같은 원유브이를 설치하는데 있어 위험요 소로 간주될 수 있는 것 중 장애물이 가장 중요한 요소이며, 다음으로 환경요소, 편리성 요소 순으로 조사되었다. 이 결과 는 원유브이 설치위치의 적정성 평가 기준 중 가중치 부여를 위한 참고자료로 사용하였다.

Table 4 Result of consultation

\begin{tabular}{|c|c|}
\hline Ordinate Concept & Result \\
\hline Obstruction & $70.0 \%$ \\
\hline Environment & $27.0 \%$ \\
\hline Convenient & $3.0 \%$ \\
\hline
\end{tabular}

\section{5. 원유브이 설치 기준 제시}

원유브이를 설치함에 있어 고려해야 할 여러 가지 요소들을 모두 충족시킬 수 있다면 가장 최선의 방안이 될 수 있으나, 현실적으로 거의 불가능하다는 점을 감안할 때에 이들 고려 요 소들에 대한 우선순위를 결정한 후, 이 순위에 입각하여 좀 더 상위 순위의 요소들이 반영된 수역에 원유브이가 설치될 수 있 도록 하여야 할 것이다. 이를 위해 의견수렴 결과와 중요도를 고려한 우선순위 결정 결과를 바탕으로 가중치를 부여하였으 며, 이들 각 요소들에 대한 최적 위치 결정 모델링 식을 구축 한 후 정량적인 수치를 기초로 원유브이 설치 적정성을 판단할 수 있도록 하였다.

\section{1 원유브이 설치위치의 적정성 평가 기준 제시}

원유브이 설치위치의 적정성을 평가하기 위하여 앞서 언급 한 바와 같이 선행연구 및 의견수렴 과정을 거쳐 Table 5 와 같 이 가중치 기준을 마련하였으며, 원유브이 설치 시 고려해야
하는 각각의 요건별로 분배율을 설정하여 원유브이 설치 위치 의 적정성 평가 기준을 제안한다.

Table 5 Installation status in domestic ports

\begin{tabular}{|c|c|c|c|}
\hline $\begin{array}{c}\text { Ordinate } \\
\text { Concept }\end{array}$ & Weight & Subordinate Concept & Weight \\
\hline \multirow{2}{*}{$\begin{array}{c}\text { Obstruction } \\
\text { Elements }\end{array}$} & 0.70 & Breakwater, Berth, Buoy & 0.25 \\
\cline { 3 - 4 } & & Fairway, Anchorage & 0.20 \\
\cline { 3 - 4 } & Water depth & 0.25 \\
\hline $\begin{array}{c}\text { Environment } \\
\text { Elements }\end{array}$ & 0.27 & Bottom materials & 0.03 \\
\cline { 3 - 4 } $\begin{array}{c}\text { Convenient } \\
\text { Elements }\end{array}$ & 0.03 & Accessibility & 0.03 \\
\hline
\end{tabular}

1) 방파제, 부두시설, 브이와 이격거리

원유브이 설치에 있어서 장애물로 작용할 수 있는 것 중 방 파제, 부두시설, 브이는 고정된 시설물로서 원유브이에 접이안 하는 선박 운항자에게 상당한 심적 부담으로 작용할 수 있으 며, 비상상황 발생 시 이에 대처 할 수 있는 시간적 여유가 없 을 뿐만 아니라, 장애물과 선박이 충돌할 경우 매우 심각한 결 과를 초래할 수 있으므로 일정거리 이상의 이격거리가 필요하 다. 그래서 본 연구에서는 선박안전기술공단 연구보고서에서 도출한 물리적인 조종영역을 참고하여 대상선박 길이의 2 배를 기준으로 Table 6과 같이 가중치 및 분배율을 제안한다.

Table 6 Consultation outline

\begin{tabular}{|c|c|c|}
\hline $\begin{array}{c}\text { Distance } \\
(\text { SBM-Breakwater, Berth, Buoy) }\end{array}$ & Distribution rate & Weight \\
\hline$<2 \mathrm{~L}$ & 0 & \\
\cline { 1 - 2 } $2 \mathrm{~L} \sim$ Under 3L & 2 & \\
\cline { 1 - 2 } & 4 & \\
\hline
\end{tabular}

2) 선박통항로 및 정박지와 이격거리

정박지와 선박 통항로의 경우도 방파제, 부두시설 및 브이 와 마찬가지로 원유브이를 이용하는 선박에게 장애물로 작용 할 수 있으므로 적정 이격거리가 필요하다. 하지만 정박지와 선박 통항로의 경우 고정된 시설물이 아니며, 긴급상황에 대처 할 수 있는 시간적 여유를 어느 정도 가질 수 있으므로 방파제, 부두시설 및 브이와의 이격거리보다 완화된 가중치 및 분배율 을 Table 7 과 같이 제안한다. 
Table 7 Consultation outline

\begin{tabular}{|c|c|c|}
\hline $\begin{array}{c}\text { Distance } \\
\text { (SBM-Fairway, Anchorage })\end{array}$ & Distribution rate & Weight \\
\cline { 1 - 2 }$\leqq$ OL & 0 & \\
\cline { 1 - 2 } Excess 0.0L $\sim$ Under 1.0L & 1 & \\
\cline { 1 - 2 } 1.0L $\sim$ Under 2.0L & 2 & \\
\hline 2.0L $\sim$ Under 3.0L & 3 & \\
\hline$\geqq 3.0 \mathrm{~L}$ & 4 & \\
\hline
\end{tabular}

3) 여유수심

원유브이를 이용하는 선박은 대부분 심흘수 선박이므로 충 분한 여유수심을 확보해야 하는데, 최소 여유수심은 $\mathrm{H} / \mathrm{d}$ (수심/ 흘수)비 1.2 이상은 확보(Woo, 1994) 되어야 한다. 하지만 수심 이 깊을수록 원유브이 및 해저배관의 설치, 점검 및 유지보수 가 어렵다는 점을 감안하여 Table 8 과 같이 가중치 및 분배율 을 제안한다.

Table 8 Consultation outline

\begin{tabular}{|c|c|c|}
\hline Water depth & Distribution rate & Weight \\
\cline { 1 - 2 }$<\mathrm{H} / \mathrm{d} 1.2$ & 0 & \\
\cline { 1 - 2 } H/d $1.2 \sim 30 \mathrm{~m}$ & 4 & \multirow{2}{*}{0.25} \\
\cline { 1 - 2 } Excess 30m $\sim 40 \mathrm{~m}$ & 3 & \\
\cline { 1 - 2 } Excess 40m $\sim 50 \mathrm{~m}$ & 2 & \\
\hline$>50 \mathrm{~m}$ & 1 & \\
\hline
\end{tabular}

4) 해저저질

해저저질은 선박이 외력의 영향으로 인해 압류되는 비상상 황의 경우 투묘를 하거나 좌초되는 상황이 발생할 수 있다. 이 때 선체 손상의 최소화 및 투묘 시 해저지질에 따른 파주력을 감안하여 해저지질에 따라 Table 9와 같이 가중치 및 분배율 을 제안한다.

Table 9 Consultation outline

\begin{tabular}{|c|c|c|}
\hline Bottom materials & Distribution rate & Weight \\
\cline { 1 - 2 } Mud, Mud/sand & 4 & \\
\cline { 1 - 2 } Sand, Shell & 3 & \multirow{2}{*}{0.03} \\
\cline { 1 - 2 } Gravel & 2 & \\
\hline Rock & 1 & \\
\hline
\end{tabular}

\section{5) 기상상태}

원유브이는 해상에 설치되기 때문에 기상에 따른 해상조건 에 영향을 많이 받는다. 이 기상조건 중 바람, 조류 및 파고에
직접적인 영향을 받는다고 하겠다. 선박이 원유브이에 접이안 하고 하역 작업을 안전하게 하기 위해서는 이러한 기상 조건들 로부터 영향을 많이 받지 않는 수역에 원유브이가 설치되어야 한다. 파고조건은 최대유의파고를 기준으로 하였으며, 바람의 경우 월별 최대풍속을 기준으로 하였으며(KMA, 2011; Yoon, 2008), 조류의 경우 선행연구조사의 내용을 참고하여(Kim, 2007) Table 10 과 같이 가중치 및 분배율을 제안한다.

Table 10 Consultation outline

\begin{tabular}{|c|c|c|c|}
\hline Item & Weather factor & $\begin{array}{c}\text { Distribution } \\
\text { rate }\end{array}$ & Weight \\
\hline \multirow{4}{*}{ Wind } & $<5 \mathrm{kts}$ & 4 & \multirow{4}{*}{0.06} \\
\hline & $5 \mathrm{kts} \sim$ Under $15 \mathrm{kts}$ & 3 & \\
\hline & $15 \mathrm{kts} \sim$ Under 30kts & 2 & \\
\hline & $>30 \mathrm{kts}$ & 1 & \\
\hline \multirow{4}{*}{ Wave } & $<1.0 \mathrm{~m}$ & 4 & \multirow{4}{*}{0.10} \\
\hline & $1.0 \mathrm{~m} \sim$ Under $2.0 \mathrm{~m}$ & 3 & \\
\hline & $2.0 \mathrm{~m} \sim$ Under $3.0 \mathrm{~m}$ & 2 & \\
\hline & $>3.0 \mathrm{~m}$ & 1 & \\
\hline \multirow{4}{*}{ Current } & $<1.0 \mathrm{kts}$ & 4 & \multirow{4}{*}{0.08} \\
\hline & $1.0 \mathrm{kts} \sim$ Under $2.0 \mathrm{kts}$ & 3 & \\
\hline & $2.0 \mathrm{kts} \sim$ Under $3.0 \mathrm{kts}$ & 2 & \\
\hline & $>3.0 \mathrm{kts}$ & 1 & \\
\hline
\end{tabular}

6) 원유브이 접근성

원유브이에 접이안하는 선박은 도선사를 승선시키게 되는데 이러한 도선사의 승선이 용이한 지점, 그리고 도선사 승선 후 원유브이로의 접근이 용이한 지점에 브이가 설치되거나 도선 점이 설정되어야 하므로 Table 11과 같이 가중치 및 분배율을 제안한다.

Table 11 Consultation outline

\begin{tabular}{|c|c|c|}
\hline Convenient factor & Distribution rate & Weight \\
\cline { 1 - 2 } Bad & 1 & \\
\cline { 1 - 2 } Good & 3 & \multirow{2}{*}{0.03} \\
\cline { 1 - 2 } Excellent & 4 & \\
\hline
\end{tabular}

\section{2 원유브이 설치위치의 적정성 평가 모델링 구축}

원유브이 설치에 있어서 최적의 위치를 선정하기 위해 각 요소들의 분배율 및 가중치 요소들을 중요도에 따라 제안하였 다. 그리고 이 값들을 단순가중치 첨가법(SAW: Simple Additive Weighting)을 사용하여 모델링을 구축하였다. 이는 각 평가기준의 상대적인 중요도에 따라 가중치를 할당하고, 각 평가기준에 가중치를 곱하고 모든 평가기준들을 합하여 전체 
점수를 산출하는 방법이다(Oh, 2008). 원유브이 설치 기준 제 시를 위한 모델링 구축 시 사용한 변수의 정의, 목적함수 및 제약조건은 다음과 같다.

$A_{i}$ : 각 요소에 가중치와 속성 분배율을 곱한 값의 총합

$w_{i}: i$ 번째 요소에 대한 가중치

$x_{i j}: i$ 번째 요소의 $j$ 번째 속성 백분율

목적함수;

$$
A_{i}=\sum_{i=1}^{I} \sum_{j=1}^{J} w_{i} x_{i j}(i=1,2 \ldots I, j=1,2 . . J)
$$

제약조건;

$$
x_{i j}>0
$$

(식 1)은 5.1절에서 제안한 각각의 고려요소들에 대해 가중 치와 속성 분배율을 곱한 후 각 요소에 대해 도출된 값들의 합 을 나타낸다. (식 2)의 제약조건은 방파제, 부두시설, 브이와의 이격거리, 선박통항로 및 정박지와 이격거리 및 여유수심이 이 에 해당한다.

제약조건을 설정한 이유는 먼저 방파제, 부두시설, 브이와 이격거리의 경우 원유브이를 이용하는 선박에게 큰 위험요소 로서 물리적인 조종영역인 2.0L미만인 경우 원유브이를 설치 할 경우 고정된 구조물과 충돌의 위험성이 높기 때문이다. 선 박통항로 및 정박지와 이격거리의 경우 방파제, 부두시설, 브 이와 같은 고정된 구조물보다 위험도가 높지 않다는 측면과 항 로나 정박지 내에 설치하지 않아야 한다는 점을 고려하여 제약 조건을 설정하였다(Park, 2010). 마지막으로 여유수심의 경우 일반적으로 $\mathrm{H} / \mathrm{d} 1.2$ 이상의 수심을 확보해야 안전성을 확보할 수 있으므로 $\mathrm{H} / \mathrm{d} 1.2$ 미만에 대해서 제약조건을 설정하였다.

\section{3 국내항의 평가 모델링 적용}

2.1절에서 조사한 현재 국내에 설치되어 있는 울산, 지세포 및 대산의 원유브이에 5.2절에서 구축한 평가모델을 적용하였 고, 그 결과는 Table 12 와 같다. Table 12 에서 1은 방파제, 부 두시설 및 브이와의 이격거리를 의미하며, 2 는 선박통항로와 정박지와의 이격거리이다. 또한 3 은 여유수심, 4 는 해저저질, 5 는 기상에 따른 해상 상태(풍속/파고/조류), 6 은 접근성을 의미 하며, 관련 데이터는 해당 항만에서 진행되었던 각종 용역 보 고서를 참고하였다.

\begin{tabular}{|c|c|c|c|c|c|}
\hline \multirow{2}{*}{ Location } & \multirow{2}{*}{$\begin{array}{c}\text { Facto } \\
\mathrm{r}\end{array}$} & \multicolumn{2}{|l|}{ Calculation } & \multirow{2}{*}{$\begin{array}{c}\text { Total } \\
A_{i}\end{array}$} & \multirow{2}{*}{ Judgement } \\
\hline & & Factor & $A_{i}$ & & \\
\hline \multirow{6}{*}{ Daesan } & 1 & $3.2 \mathrm{~L}$ & 1.00 & \multirow{6}{*}{2.45} & \multirow{6}{*}{$\begin{array}{l}\text { Appropriat } \\
\text { e location }\end{array}$} \\
\hline & 2 & $0.3 \mathrm{~L}$ & 0.20 & & \\
\hline & 3 & $31 \mathrm{~m}$ & 0.75 & & \\
\hline & 4 & M & 0.12 & & \\
\hline & 5 & $\begin{array}{c}25.5 \mathrm{kts} / 5.1 \mathrm{~m} / 2.0 \mathrm{kt} \\
\mathrm{s}\end{array}$ & 0.38 & & \\
\hline & 6 & Good & 0.09 & & \\
\hline \multirow{6}{*}{ Jisepo } & 1 & $2.7 \mathrm{~L}$ & 0.50 & \multirow{6}{*}{2.69} & \multirow{6}{*}{$\begin{array}{l}\text { Appropriat } \\
\text { e location }\end{array}$} \\
\hline & 2 & - & 0.80 & & \\
\hline & 3 & $32 \mathrm{~m}$ & 0.75 & & \\
\hline & 4 & S & 0.09 & & \\
\hline & 5 & $18.1 \mathrm{kts} / 4.0 \mathrm{~m} / 1.0 \mathrm{kts}$ & 0.46 & & \\
\hline & 6 & Good & 0.09 & & \\
\hline \multirow{6}{*}{$\begin{array}{c}\text { Ulsan } \\
\text { (SK \#2) }\end{array}$} & 1 & $3.1 \mathrm{~L}$ & 1.00 & \multirow{6}{*}{3.15} & \multirow{6}{*}{$\begin{array}{l}\text { Appropriat } \\
\text { e location }\end{array}$} \\
\hline & 2 & $1.8 \mathrm{~L}$ & 0.40 & & \\
\hline & 3 & $25 \mathrm{~m}$ & 1.00 & & \\
\hline & 4 & M & 0.12 & & \\
\hline & 5 & $18.3 \mathrm{kts} / 4.7 \mathrm{~m} / 0.6 \mathrm{kts}$ & 0.54 & & \\
\hline & 6 & Good & 0.09 & & \\
\hline
\end{tabular}

Table 12 Verification of installation standards

\section{4 모델의 적용을 통한 원유브이 설치 기준 제시}

5.2절에서 구축한 모델식을 바탕으로 원유브이 설치 기준을 제안하면 Table 13과 같다. 즉, 제약식인 (식 2)의 조건을 충족 하지 못할 경우는 원유브이 설치 위치로 불가능하다. 또한, $A_{i}$ 의 기준값으로 국내항의 최소값인 대산항의 값(2.45)을 설정하 였는데, 대산항의 경우 다른 항에 비해 항로와 인접하고 기상 상태가 상대적으로 좋지 않은 곳에 원유브이가 설치되어 있으 나 그 동안 큰 문제없이 운영되어 왔다는 점을 감안하였다. 이 러한 기준값을 기반으로 $A_{i}$ 의 값이 2.44 이하인 경우 조건부 로 설치 가능하며, 2.45 이상일 경우 원유브이 설치위치로서 적 당하다는 원유브이 설치에 있어서의 조건을 제시한다.

Table 13 Judgement Standard

\begin{tabular}{|c|c|}
\hline $\begin{array}{c}\text { Judgement Criteria } \\
\left(A_{i}\right)\end{array}$ & Judgement \\
\hline 제약조건을 만족하지 못한 경우 & Impossible location \\
\hline$A_{i} \leqq 2.44$ & Conditional installation \\
\hline $2.45 \leqq A_{i}$ & Appropriate location \\
\hline
\end{tabular}




\section{6. 결 론}

본 연구에서는 국내 및 국외에 설치되어 운영되고 있는 원 유브이를 장애물과의 거리, 설치 수심 및 기상에 따른 해상 상태 등으로 분류하여 비교 분석하였다. 또한 국내외에서 원 유브이 설치에 관한 연구자료 및 일반적으로 원유브이 설치 시 참고사항으로 활용하고 있는 관련 규정을 살펴보고 원유 브이 설치 기준 제시를 위한 방안을 검토하였다. 그리고 정 량적인 기준 제시를 위해 원유브이 설치 시 고려해야하는 요 인을 도출하고, 그 결과를 바탕으로 전문가 집단을 대상으로 설문조사를 실시하였다. 그 후 도출된 자료를 바탕으로 각 요인에 대한 가중치 및 분배율을 제안하였으며, 이를 바탕으 로 수리적인 모델식을 통한 원유브이 설치 기준을 제시하였 다.

본 연구에서 제시된 모델의 목적식은 장애물과의 거리, 항 로 및 정박지와의 거리, 수심, 해저저질, 환경조건, 편리성 조 건 등 총 6 가지 요소들로 이루어진다. 그리고 제약식은 일정 이상의 장애물과 이격거리 및 항로 및 정박지와 이격거리, 일정이상의 수심을 나타내는 식으로 구성되어 있다. 본 연구 에서 제안한 설치 기준값은 다소 열악한 환경이지만 큰 문제 없이 원유브이를 잘 운영하고 있는 국내항의 최소값인 대산 항의 값으로 설정하였다. 본 연구를 통해 제시한 원유브이 설치 기준을 기반으로 향후 신설될 원유브이에 적용할 수 있 을 것이라고 판단된다.

향후 연구 과제로는 원유브이 설치 시 고려해야 할 요건들 에 대한 선박조종시뮬레이션 실험을 통해 좀 더 체계적인 설 치 기준 제시가 필요할 것으로 판단되며, 본 연구를 통해 제 안된 설치 기준을 입지선정 프로그램에 적용할 수 있는 연구 가 필요하다고 사료된다.

\section{참 고 문 헌}

[1] Kim, M, K(2007), A Study on Analysis the Cause of Damage of Light Beacon by Natural Disaster and Improvement of Structure, Kwandong University a Master's Degree Thesis, Vol. 128, pp. 21-52.

[2] Korea Institude of Maritime and Fisheries Technology(1999), A Review Report on management safety of No. 2 \& 3 Buoy According to the Construction of the Central Breakwater.

[3] KMA(Korea Meteorological Administration(2011), Clima- tological Normals of Korea, http://www.kma.go.kr

[4] Korea Ship Safety Technology Authority(2007), A Study on the Maneuvering Area of Ship in Moving at Single Point Mooring.
[5] Oh, S. W.(2008), A Study on the Location Analysis Using Spatial Analysis and Ordered Weighted Averaging(OWA) Operator Weighting Functions, Korea Maritime University a Doctor's Degree Thesis, pp. 14-21.

[6] Park, S. H.(2010), "The Study on a Marina's Construction Location Analysis Using Integer Optimization Programming", Korea Institute of Navigation and Port Research(KINPR) Press, Vol. 34, No. 1, pp. 54-59.

[7] Rotterdam/Europort, The Model Test of Very Large Crude Oil Tanker in Narrow Channel.

[8] Shipping Guide Ltd.(2010), Guide to port entry.

[9] Woo, B. G. and Ji, S. W., Approaching to a SBM of VLCC using the Woo's Approach, Journal of Korean Institute of Navigation, Vol. 18, No.1, pp.32-33.

[10] Yoo, C. I., Yoon, H. S. and Park, H. B.(2008), "Correlation between Spring Weather Factors and Local Wind Waves in the Nakdong River Estuary, Korea", Korea Society of Marine Environmnet and Safety( KOSOMES) Press, Vol. 14, No. 2, pp. 119-125.

원고접수일 : 2013년 6월 7일

심사완료일 : 2013년 8월 12일

원고채택일 : 2013년 8월 12일 